\title{
Myocardial Repair with Long-Term and Low-Dose Administration of a Nitric Oxide Synthesis Inhibitor. Myofibroblasts, Type III Collagen and Fibronectin
}

\author{
Mônica Gomes Pessanha, Myriam Dumas Hahn, Carlos Alberto Mandarim-de-Lacerda
}

Rio de Janeiro, RJ - Brazil

Objective - To study the healing process of the myocardium in hypertensive rats undergoing inhibition of nitric oxide synthesis.

Methods - Two groups of animals were studied: one received L-NAME, $12 \mathrm{mg} / \mathrm{kg} /$ day, and the other was a control group. The presence of type III collagen, fibronectin, and $\alpha$-smooth muscle actin-positive cells was assessed by immunohistochemistry.

Results - Fibronectin was seen in both early and late lesions, while type III collagen was seen mainly in areas of incomplete healing, situated among myocytes and around the intramyocardial branches of the coronary arteries. Areas representing early and late lesions showed a population of spindle-shaped cells. Immunohistochemistry showed that these cells were positive for $\alpha$-smooth muscle actin.

Conclusion - In the myocardium of hypertensive rats, the $\alpha$-smooth muscle actin-positive cells are related to the accumulation of type III collagen and fibronectin in the areas of myocardial damage.

Key words: myofibroblasts, nitric oxide, myocardial remodeling, $\alpha$-smooth muscle actin
Instituto de Biologia Roberto Alcântara Gomes-UERJ - Departamento de Patologia Experimental, Hospital Antônio Pedro - UFF. Funding: CNPq (Processes \#s. 57.41.14/97-1 e 13.82.14/96-4) and Faperj (Process E-26/170.770/98).

Mailing Address: Mônica G. Pessanha - Centro Biomédico, Inst. de Biologia UERJ - Av. 28 de Setembro, 87 (fundos) - 20551-030 - Rio de Janeiro, RJ - Brazil
The discovery of the role of nitric oxide (NO) in the maintenance of vascular tonus led to the development of an experimental model for hypertension induced by the chronic inhibition of the NO synthase (NOS), the enzyme responsible for the synthesis of NO from the amino acid L-arginin ${ }^{1,2}$. This experimental model for hypertension, known as "NOdeficient hypertension" ${ }^{3}$,inspired a series of studies aimed at defining the structural and functional features of the heart in this kind of hypertension ${ }^{47}$.

The $\mathrm{N}^{\mathrm{G}}$-nitro-L-arginine methyl ester(L-NAME) is one of the most well known NOS inhibitors and is commonly used in experimental models ${ }^{8,9}$. The continuous use of this compound leads to the development of high blood pressure (HBP) as a result of generalized vasoconstriction ${ }^{2,9,10}$, reduction in the intracellular levels of cGMP, and morphological changes in the renal microvasculature ${ }^{11,12}$.

The use of high doses of L-NAME leads to the development of marked hypertension in rats ${ }^{2,8,9}$. The effects of this kind of NOS inhibition were studied using stereology to examine the structural changes in the myocardium. Significant changes, such as an increase in the size of myocytes, and interstitial and perivascular fibrosis, were shown ${ }^{8,13,14}$.

Left ventricular hypertrophy ( $\mathrm{LVH}$ ) is one of the most common manifestations of HBP. When LVH is caused by HBP, it involves 2 different, but interrelated, processes. The first process is myocyte hypertrophy and the second is an increased synthesis of fibrillar collagens, mainly type I and type III ${ }^{15-17}$. Myocyte death has been suggested as one of the factors that accounts for the increased amount of collagen (substitutive fibrosis). ${ }^{16,18,19}$. However, this topic is controversial ${ }^{15,20,21}$.

The extracellular matrix (ECM) is the myocardial compartment mostly involved in the process of myocardial healing following the loss of myocytes ${ }^{22-24}$. At the site of the lesion, the ECM consists of macromolecules that are responsible for the formation of the fibrin-fibronectin network and for the invasion by neutrophils, monocytes, macrophages, fibroblasts and phenotypically transformed fibroblasts (myofibroblasts [MFs]) ${ }^{24}$. 
MFs show features of both fibroblasts and smooth muscle cells, and the characterization of MFs is based on ultrastructural criteria ${ }^{25,26}$. The production of collagen by MFs is regulated by autocrine and paracrine signs. MFs are also related to the production of cellular fibronectin ${ }^{23-24,27,28}$.

The main components of the myocardial ECM are type I and III fibrillar collagen and fibronectin ${ }^{29-31}$. Changes in the amount and distribution of these proteins are mainly related to changes in heart function; thus, these changes may also affect myocardial compliance ${ }^{32-34}$.

According to previous studies of cardiac hypertrophy in rats caused by pressure overload, the presence of fibronectin in ischemic myocardial areas precedes the development of collagen ${ }^{29,31}$. In addition, other experimental studies have shown that the general myocardial healing process is characterized by an initial accumulation of fibronectin which, in the late stages of this process, is associated with an increase in collagen production ${ }^{34-36}$.

The objective of this report is to study the healing process of the myocardium during the experimental inhibition of NO synthase.

\section{Methods}

Male and female Wistar rats weighing 250-300g were used in this study. The rats were divided into 2 groups: a control group and an L-NAME group, having 10 and 14 animals, respectively. The rats were fed a standard diet and unrestricted water. The rats in the L-NAME group were given the NO synthase inhibitor $\left(\mathrm{N}^{\mathrm{G}}\right.$-nitro-L-arginine methyl ester hydrochloride, Sigma Co, lot 44H0102) at a dosage of $12 \mathrm{mg} / \mathrm{kg} /$ day for 15 weeks. The blood pressure (BP) in the tail was measured weekly with the use of a plethysmograph ${ }^{37}$. After the rats were anesthetized with ethyl ether, their hearts were exposed and a high volume of $10 \% \mathrm{KCl}$ was injected in the left ventricle (LV). This procedure induced heart arrest in diastole.

A series of fragments of the free left ventricular wall were obtained and fixed by immersion in a solution of $4 \%$ formalin and phosphate buffer $(\mathrm{pH} 7.2)$ at room temperature. The samples were subsequently dehydrated in increasing concentrations of ethanol, embedded in paraffin and cut in sections of $5 \mu \mathrm{m}$ thickness. The sections were then stained with hematoxylin-eosin and Masson's trichrome.

The tissue blocks employed for light microscopy were also used for immunohistochemistry. Paraffin sections of $5 \mu \mathrm{m}$ thickness were applied to glass slides, which were pretreated with Silano ${ }^{\circledR}$ to warrant a better adherence of the section to the glass slide during the various stages of the technique. The presence of type III collagen, fibronectin and $\alpha$-smooth muscle actin-positive cells ( $\alpha$-SMA) was examined with the use of the avidin-biotin peroxidase method. Protein digestion with $1 \%$ trypsin was performed only to assess the presence of type III collagen. The sections were incubated with rabbit polyclonal antibodies specific for type III collagen (Pharmigen, AB757), in the dilution of 1:200. They were also incubated with fibronectin (Pharmigen, AB1942), in the dilution of 1:300 and with mouse monoclonal antibody specific for $\alpha$-SMA (DAKO, M851), in the dilution of 1:200. Peroxidase activity was shown in a solution of diaminobenzidine tetrahyhdrochloride (Sigma Co., 5mg) in 10ml of TRIS at pH 7.0, containing $200 \mu \mathrm{l}$ of $10 \%$ hydrogen peroxide at room temperature. The positive control for type III collagen was performed through the observation of the positivity of the tunica adventitia of the intramyocardial branches of the coronary arteries of the rats in the control and L-NAME groups. For fibronectin, this same control was performed with the use of kidneys from control rats, in which the glomerular positivity was observed. The negative control was performed omitting the primary antibody.

The differences in BP levels between the L-NAME and control groups were tested with the Student's $t$ test, with a level of significance of $0.05^{38}$.

\section{Results}

In the control group, BP remained unchanged during the entire experiment. In the L-NAME group, however, BP increased gradually up to $150.0 \mathrm{mmHg}$ after the $10^{\text {th }}$ week of the experiment (tab. I).

At light microscopy, the myocardium of the animals undergoing NO synthase inhibition showed multiple areas of myofibrillar degeneration, necrosis and fibrosis, greatly evidenced in the free wall of the LV. After 100 days using LNAME, necrotic myofibers characterized by acidophilic stain of the cytoplasm, loss of striations and, sometimes, focal groups of lymphocytes, were observed in all specimens studied. Neutrophils were sometimes observed, especially in early lesions. A diffuse increase in the interstitial collagenous connective tissue next to the vessels was frequently seen. In contrast, the animals in the control group did not show any sign of myocardial damage.

In the myocardium of the control group, the immunoreactivity to type III collagen was identified as a delicate septum among and surrounding the muscular fibers. In the tunica adventitia of the intramyocardial coronary arteries, a

\begin{tabular}{|c|c|c|c|}
\hline \multicolumn{4}{|c|}{$\begin{array}{l}\text { Table I - Blood pressure in the tail measured in animals of control } \\
\text { and L-NAME groups }\end{array}$} \\
\hline Weeks & Control & L-NAME & $\mathrm{p}$ \\
\hline $\begin{array}{l}\text { Before the administration of L- } \\
\text { NAME }\end{array}$ & $99.4 \pm 1.0$ & $99.6 \pm 1.7$ & 0.78 \\
\hline \multicolumn{4}{|c|}{ After the administration of L-NAME } \\
\hline $4^{\text {th }}$ & $99.5 \pm 0.7$ & $114.5 \pm 1.3$ & $<0.0001$ \\
\hline $8^{\text {th }}$ & $99.9 \pm 0.3$ & $127.9 \pm 2.6$ & $<0.0001$ \\
\hline $10^{\text {th }}$ & $100.8 \pm 0.5$ & $142.9 \pm 2.6$ & $<0.0001$ \\
\hline $13^{\text {th }}$ & $101.0 \pm 2.1$ & $150.0 \pm 1.8$ & $<0.0001$ \\
\hline $14^{\text {th }}$ & $101.5 \pm 2.4$ & $150.0 \pm 2.1$ & $<0.0001$ \\
\hline $15^{\text {th }}$ & $102.5 \pm 2.6$ & $150.0 \pm 2.2$ & $<0.0001$ \\
\hline $\begin{array}{l}\text { (mean } \pm \text { standard deviation); } \\
\text { between the groups to be sig }\end{array}$ & $\begin{array}{l}\text { licates the } \\
\text { nt. }\end{array}$ & lihood of & difference \\
\hline
\end{tabular}


positive immunoreactivity to type III collagen, spreading among the viable muscle fibers, was similarly noted. The myocardium of the L-NAME group showed an increased amount of type III collagen among the muscular fibers and within the tunica adventitia of intramyocardial coronary arteries. Type III collagen and fibronectin were noted in the various foci of early and late myocardial lesions (figs. 1a-d).

There was an increased and uniform distribution of fibronectin in the foci of myocardial lesions filled with nonmuscular cells, i.e., endothelial cells, fibroblasts, MFs, neutrophils and macrophages. These foci were morphologically characterized as having early lesions. There was also a clear distribution of fibronectin in the foci of incompletely healed late lesions.

Type III collagen showed a more uniform distribution in late lesions; however, it was also present in early lesions, although randomly distributed. An increased intercellular space and accumulation of type III collagen and fibronectin in noninfarcted myocardial areas of L-NAME rats were also noted.

Concomitantly, numerous spindle-shaped cells with morphological features of interstitial fibroblasts and positivity for $\alpha$-SMA (Fig. 1e) were seen in early and late lesions. The vascular smooth muscle cells were also $\alpha$-SMApositive and, in the healthy myocardium, they were the only cells with positivity for this antibody (fig. 1f).

\section{Discussion}

The collagenous component of the healthy myocardium is part of a system that contains a series of constituents of the ECM (heart interstitium). Its main components are type I and III collagens, organized in a tridimensional network around cardiac myocytes ${ }^{39-41}$. These elements are responsible for the viscoelastic properties of the myocardium, which are mainly related to the type and proportions of fibrillar proteins and glycoproteins, as well as to the interaction of these proteins with the myocytes. ${ }^{39,40}$. An increase in the content or transformation of the structure of these fibrillar components in relation to cardiac muscle fibers could affect myocardial compliance ${ }^{21,42,43}$.

The role of the myocytes and of the cardiac interstitium in the dysfunction of the heart is still controversial ${ }^{4,9}$. However, previous studies have shown an increase in the volume fraction of collagen in $\mathrm{LVH}$ as a result of pressure overload $^{12,16,44-47}$.

The inhibition of NO biosynthesis using high doses of L-NAME induces a significant elevation of the blood pressure, $\mathrm{LVH}$, myocyte necrosis, vascular damage, and interstitial fibrosis ${ }^{2,9,14,48}$. The current results with the lowdose and long-term administration of L-NAME showed that the pressure levels were not so high as those observed in other studies, but myocardial abnormalities were similar to those in the model with high-dosage and short-term administration of L-NAME ${ }^{8,44}$. When NOS is experimentally inhibited, most myocardial abnormalities are probably the result of a compensatory response to the overload of the
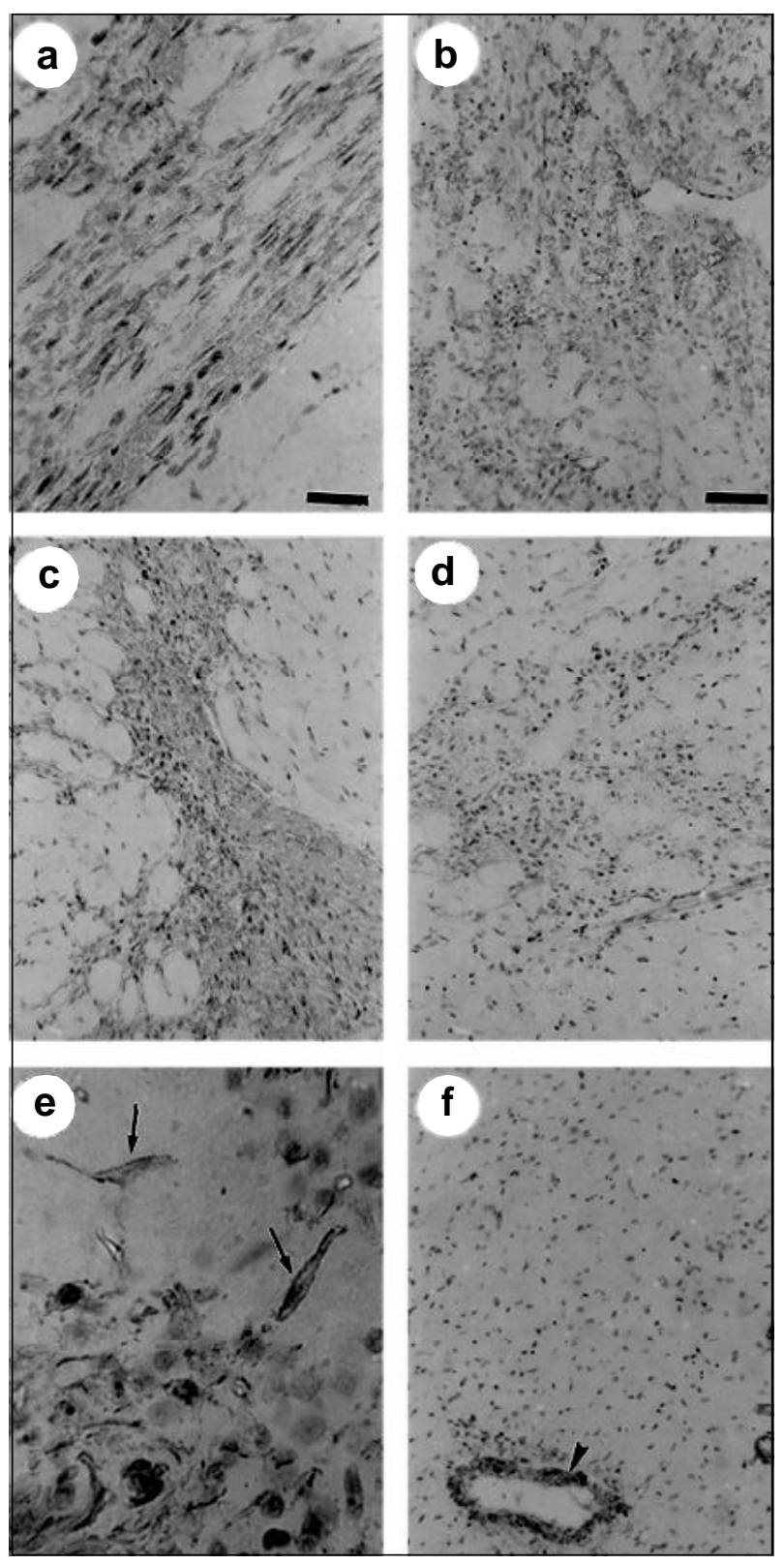

Fig. 1 - Photomicrographies of the areas of myocardial lesions in hypertensive rats during the inhibition of nitric oxide synthesis. A) immunostaining anti-type III collagen, accumulation of type III collagen in an area of myocardial necrosis with incomplete healing; B) a delicate network of type III collagen in an area of early lesion, with abundant cellular inflammatory infiltrate; C) immunostaining antifibronectin, accumulation of fibronectin in an area of late lesion with incomplete healing; D) fibronectin network in an area of early lesion; E) photomicrography of an area of myocardial lesion in hypertensive rats during the inhibition of nitric oxide synthesis. Spindle $\alpha$-SMA-positive cells are noted (arrows); F) photomicrography of normal rat myocardium showing $\alpha$-SMA positivity only in vascular smooth muscle cells (arrowhead). Magnification (represented by the bar): $50 \mu \mathrm{m}$ in a; $120 \mu \mathrm{m}$ in $b$-d and $f ; 30 \mu m$ in $e$.

circulatory system ${ }^{49}$. However, the extensive myocardial fibrosis noted in these cases does not seem to be related solely to the ventricular overload, but rather to the use of LNAME, probably as a result of the myocardial ischemia inherent to this experimental model ${ }^{9}$.

In chronic heart failure, changes in the composition of the connective tissue are mainly related to systolic and 
diastolic dysfunction, whereas in acute heart failure, the changes occur mainly in the myocytes ${ }^{50}$. Clinical and experimental studies have shown that the ventricular dysfunction induced by pressure overload relates more to the duration of the overload and to the nature of the stimulus than to the extent of the hypertrophic process ${ }^{8,9,47,51-53}$.

Maintenance of the hypertensive stimulus for 15 weeks induced myocardial remodeling, which showed cellular elements of the inflammatory cell infiltrate and deposits of connective tissue. This latter may have occurred as a result of the synthesis of the inflammatory cells and/or from their growth factors. Myocardial lesions with loss of myocytes, characterized by the presence of foci of myocytolysis and necrotic myofibers, were also observed.

According to previous studies, there is an association between the responses of the ECM and the cardiomyocytes when the stimulus to the overload is sustained ${ }^{54-56}$. However, it has not yet been clarified if the changes in the components of the ECM are merely a response to the necrosis of myocytes and/or if these changes induce cellular loss 9,20-21,57,58.

In the present study, immunostaining for fibronectin was observed in early myocardial lesions. This immunostaining was noted mainly in areas of myocyte loss, probably as a result of the diffusion of fibronectin that originated from platelets or of the diffusion of plasma into necrotic cardiac myocytes ${ }^{23}$. Fibronectin was also present in late lesions, although the healing tissue does not usually show this $\operatorname{protein}^{33}$.

Many functions have been attributed to the increased content of fibronectin in myocardial infarction, including the chemotactic action. Fibronectin plays a role as a sustaining network for the growth and migration of endothelial cells and fibroblasts, and it contributes to platelet aggregation. The presence of fibronectin in myocardial lesions is also related to the angiogenic process that occurs during the healing of the infarction ${ }^{59}$. It may also work as a temporary matrix for deposition and remodeling of other EMC proteins, mainly collagen ${ }^{33,42,60}$.

Type III collagen was noted in early lesions or in areas of incomplete healing, as well as in intermuscular spaces and in the tunica adventitia of the L-NAME animals. In accordance with previous studies, the presence of type III collagen in areas of interstitial fibrosis is important for the maintenance of the cell-to-cell relation and for the distribution of the mechanical forces during myocyte contraction ${ }^{61,62}$.

The elongated cells noted in areas of myocardial lesions may be remnants of endothelial cells from infarcted areas or even MFs contributing to the local synthesis of ECM proteins ${ }^{22,23,59,63}$.

Cardiac response to pressure overload is characterized by the genetic reexpression of a series of fetal proteins of the ECM ${ }^{27,31}$. Previous studies have shown that the components of the ECM may modulate the phenotypic features of the fibroblasts, increasing or decreasing the expression by these cells of $\alpha$-SMA, the typical actin isoform of smooth muscle cells ${ }^{24-25,34}$. The presence of MFs during the deposition of connective tissue suggests the regulatory function of these cells in the remodeling of the ECM, mainly through the production of fibronectin and type III collagen ${ }^{22}$.

The experimental model of NOS inhibition ${ }^{47}$ shows myocyte hypertrophy, a factor that could account for the expression of $\alpha$-SMA in MFs. As described in previous studies, in addition to growth factors (mainly transforming growth factor $\beta$ ), the mechanical deformation is a significant factor that accounts for the expression of $\alpha$-SMA in fibroblasts ${ }^{26,64}$. Willems et al ${ }^{26}$ believe that the abundance of myofibroblasts in myocardial lesions is related to the maintenance of myocardial compliance, preventing the rupture of the affected area during the rhythmic contractile cycles of the heart.

\section{References}

1. Bayliss C, Mitruka B, Deng A. Chronic blockade of nitric oxide synthesis in the rat produces systemic hypertension and glomerular damage. J Clin Invest 1992; 90: 278-81.

2. Ribeiro MO, Antunes E, Nucci G, Lovisolo SM, Zatz R. Chronic inhibition of nitric oxide synthesis:a new model of arterial hypertension. Hypertens 1992; 20: 298-303.

3. Danaberg J, Sider RS, Grekin RJ. Sustained hypertension induced by orally administered nitro-L-arginine. Hypertension 1993; 21: 359-63.

4. Arnal JF, Amrani EL, Chatellier G, Menard J, Michel JB. Cardiac weight in hypertension induced by nitric oxide synthase blockade. Hypertens 1993; 22: 380-7.

5. Morton JJ, Beattie EC, Speirs A, Gulliver F. Persistent hypertension following inhibition of nitric oxide formation in the young wistar rat: role of renin and vascular hypertrophy. J Hypertens 1993; 11: 1083-8.

6. Bernátová I, Pechánová O. NO-deficient hypertension induced by L-NAME treatment in rats. J Mol Cell Cardiol 1994; 26: 123.

7. Gerová M, Hartmannová B, Dolezel S, Jezek L. Long-term inhibition of NO synthase induces cardiac hypertrophy with a decrease in adrenergic innervation. Physiol Res 1996; 45: 339-44.
8. Pereira LMM, Vianna GMM, Mandarim-de-Lacerda. Stereology of the myocardium in hypertensive rats. Differences in relation to the time of inhibition of nitric oxide synthesis. Virchows Arch 1998; 433: 369-73.

9. Moreno H, Metze K, Bento AC, Antunes E, Zatz R, Nucci G. Chronic nitric oxide inhibition as a model of hypertensive heart muscle disease. Basic Res Cardiol 1996; $91:$ 248-55.

10. Gardiner SM, KempPA, Bennett T, Palmer RMJ, Moncada S. Nitric oxide synthase inhibitors cause sustained, but reversible, hypertension and hindquaters vasoconstriction in Brattleboro rats. Eur J Pharmacol 1992; 213: 449-51.

11. Palmer RMJ, Ferrige AG, Moncada S. Nitric oxide release accounts for the biological activity of endothelium-derived relaxing factor. Nature 1987; 327: 524-6.

12. Numaguchi K, Egashira K, Takemoto M, et al. Chronic inhibition of nitric oxide synthesis causes coronary microvascular remodeling in rats. Hypertens 1995 26(part 1): 957-62.

13. Mandarim-de-Lacerda CA, Pereira LMM. Stereology of the myocardium in hypertensive rats under chronic inhibition of nitric oxide synthesis. Biomed Res 1997; 8: 153-60. 
14. Pereira LMM, Mandarim-de-Lacerda CA. Estereologia do miocárdio em ratos hipertensos pelo uso de inibidor da síntese do óxido nítrico. Rev Port Cardiol 1997; 16: 753-8.

15. Brilla GB, PickR, Tan LB, Joseph SJ, Weber KT. Remodeling of the rat right and left ventricles in experimental hypertension. Circ Res 1990; 67: 1355-64.

16. Weber KT, Janicki JS, Pick R, Capasso J, Anversa P. Myocardial fibrosis and pathologic hypertrophy in the rat with renovascular hypertension. Am J Cardiol 1990; 65: 1G-7G

17. Weber KT, Brilla CG. Pathologic hypertrophy and cardiac interstitium. Circulation 1991; 83: 1849-65.

18. Anversa P, Kajstura J, Cheng W, Krzysztof R, Cigola E, Olivetti G. Insulin-like growth factor-1 and myocyte growth:the danger of a dogma. Part II. Induced myocardial growth: pathologic hypertrophy. Cardiovasc Res 1996; 32: 484-95.

19. Okoshi MP, Matsubara LS, Franco M, Cicogna AC, Matsubara BB. Myocyte necrosis is the basis for fibrosis in renovascular hypertensive rats. Braz J Med Biol Res 1997; 30: 1135-44.

20. Doering CW, Jalil JE, Janicki JS, et al. Collagen network remodeling and diastolic stiffness of the rat left ventricle with pressure overload hypertrophy. Cardiovasc Res 1988; 22: 686-95.

21. Jalil JE, Doering CW, Janick JS, Pick R, Clarck WA, Weber KT. Structural vs contractile protein remodeling and myocardial stiffness in hypertrophied rat left ventricle. J Mol Cell Cardiol 1988; 20: 1179-87.

22. Leslie KO, Taatjes DJ, Schwarz J, von Turkovich M, Low RB. Cardiac myofibroblasts express alpha smooth muscle actin during righ ventricular pressure overload in the rabbit. Am J Pathol 1991; 139: 207-16.

23. Willems IEMG, Arends J-W, Daemen MJAP. Tenascin and fibronectin expression in healing human myocardial scars. J Pathol 1996; 179: 321-5.

24. Weber KT. Metabolic responses of extracellular matrix in tissue repair. Annals of Medicine 1997; 29: 333-8.

25. Gabbiani G, Ryan GB, Majno G. Presence of modified fibroblasts in granulation tissue and their possible role in wound contraction. Experientia 1971; 27: 548-50.

26. Willems IEMG, Havenith MG, Mey JGR, Daemen MJAP. The a-smooth muscle actin-positive cells in healing human myocardial scars. AM J Pathol 1994; 145: 868-75.

27. Samuel JL, Barrieux A, Dufour S. Accumulation of fetal fibronectin mRNA during the development of rat cardiac hypertrophy induced by pressure overload. J Clin Invest 1991; 88: 1737-46.

28. Zhou G, Kandala JC, Tyagi SC, Katawa LC, Weber KT. Effects of angiotensin II and aldosterone on collagen gen expression and protein turnover in cardiac fibroblasts. Moll Cell Biochem 1996; 154: 171-8.

29. Contard F, Koteliansky V, Marotte F, Dubus I, Rapapport L, Samuel J-L. Specific alterations in the distribution of extracellular matrix components within rat myocardium during the development of pressure overload. Lab Invest 1991; 64: 65-74.

30. Cleutjens JPM, Kandala JC, Guarda E, Guntaka RV, Weber KT. Regulation of collagen degradation in the rat myocardium after infarction. J Mol Cell Cardiol 1995a; 27: 1281-92

31. Farhadian F, Contard F, Sabri J, Samuel L, Rappaport L. Fibronectin and basement membrane in cardiovascular organogenesis and disease pathogenesis. Cardiovasc Res 1996; 32: 433-42.

32. Cleutjens JPM, Verluyten MJA, Smits JFM, Daemen MJAP. Collagen remodeling after myocardial infarction in the rat heart. Am J Pathol 1995b; 147: 325-38.

33. Shekhonin BV, Domogatsky SP, Idelson GL, Koteliansky VE. Participance of fibronectin and various collagen types in the formation on fibrous extracellular matrix in cardiosclerosis. J Mol Cell Cardiol 1988; 20: 501-8.

34. Weihrauch D, Zimmermann R, Arras M, Schaper J. Expression of extracellular matrix proteins and the role of fibroblasts and macrophages in repair processes in ischemic porcine myocardium. Cell Mol Biol Res 1994; 40: 105-16.

35. Knowlton AA, Connelly CM, Romo GG, Mamuya W, Apstein CS, Bnrecher P. Rapid expression of fibronecti in the rabbit heart after myocardial infarction with and without reperfusion. J Clin Invest 1992; 89: 1060-8.

36. Grimm D, Kromer EP, Bocker W, et al. Regulation of extracellular matrix proteins in pressure-overload cardiac hypertrophy: effects of angiotensin converting enzyme inhibition. J Hypertens 1998; 16: 1345-55.

37. Zatz R. A low cost tail-cujj method for the estimation of mean arterial pressure in concious rats. Lab. Anim Sci 1990; 40: 198-201.

38. Zar H. Biostatistical Analysis. Upper Saddle River, Prentice Hall, 1996.
39. Borg TK, Caulfield JB. The collagen matrix of the heart. Federation Proc 1981; 40: 2037-41.

40. Weber KT. Cardiac Interstitium: extracellular space of the myocardium. In: Fozzard HA. (ed) - The Heart and Cardiovascular System. New York: Raven, 1992: 1465-80

41. Cleutjens JPM. The role of matrix metalloproteinases in heart disease. Cardiovasc Res 1996; 32: 816-21.

42. Villarreal FJ, Dillmann WH. Cardiac hypertrophy-induced changes in mRNA levels for TGF- $\beta_{1}$, fibronectin, and collagen. Circ Physiol 1992; 31: H1861-H16.

43. Ahumada GG, Saffitz JE. Fibronectin in rat heart. A link between cardiac myocytes and collagen. J Histochem Cytochem 1984; 32: 383-8.

44. Sládek T, Gerová M, Znojil V, Devát L. Morphometric characteristics of cardiac hypertrophy induced by long-term inhibition of NO synthase. Physiol Res 1996; 45: 335-8.

45. Meerson F. Contractile Function of the heart in hiperfunctional hypertrophy and heart failure. Circ Res 1969; II14: 9-54

46. Collins JF, Pawloki-Dahm C, Davis MG, Ball N, Dorn GW, Walsh RA. The role of the cytokeleton in left ventricular pressure overload hypertrophy and failure. J Mol Cell Cardiol 1996; 28: 1435-43.

47. Pessanha MG, Mandarim-de-Lacerda CA, Hahn MD. Stereology and immunohistochemistry of the myocardium in experimental hypertension: long-term and low-dosage administration of inhibitor of the nitric oxide synthesis. Pathobiol 1999; 67: 26-33.

48. Pereira LMM, Mandarim-de-Lacerda CA. Morfologia del miocardio en ratas sometidas a inhibicion cronica de la sintesis de oxido nitrico. Rev Chil Anat 1996; 14: 147-55.

49. Leonetti G, Cuspidi C. The heart and vascular changes in hypertension. J hypertens 1995; 13 (suppl 2): S29-S34.

50. Hess OM, Villari B, Krayunbuehl HP. Diastolic dysfunction in aortic stenosis. Circulation 1993; 87: IV73-IV76.

51. Kannel WB. Implications of Framingham study data for treatment of hypertension: impact of other risk factors. In: Laragh JH, Buhler FR, Seldin SW (eds) Frontiers in Hypertension Research. New York, Heidelberg, Berlin: Springer, 1981: 17-21.

52. Pfeffer JM, Pfeffer MA, Mirsky I, Braunwald E. Regreesion of left ventricular dysfunction by captopril in the spontaneously hypertensive rat. Proc Natl Acad Sci USA 1982; 79: 3310-14.

53. Gavras H. Hypertension and congestive heart failure:Benefits of converting enzyme inhibition (Captopril). J Am Coll Cardiol 1983; 1: 518-20.

54. Medugorac I. Collagen content in different areas of normal and hypertrophied rat myocardium. Cardiovasc Res 1980; 14: 551-4.

55. Weber KT, Clark WA, Janicki JS, Shroff SG. Physiological versus pathologic hypertrophy and the pressure overloaded myocardium. J Cardiovasc Pharmacol 1987; 10: 537-50.

56. Omens JH, Milkes DE, Covell JW. Effects of pressure overload on the passive mechanics of the rat left ventricle. Ann Biomed Engineer 1995; 23: 152-63.

57. Weber KT. Cardiac interstitium in health and disease:the fibrillar collagen network. J Am Coll Cardiol 1989; 13: 1637-52.

58. Silver MA, Pick R, Brilla CG, Jalil JE, Janicki JS, Weber KT. Reactive and reparative fibrillar collagen remodelling in the hypertrophied rat left ventricle: two experimental models of myocardial fibrosis. Cardiovasc Res 1990; 24: 741-7.

59. Casscells W, Kimura H, Sanchez JA, Ferrans VJ. Immunohistochemical study of fibronectin in experimental myocardial infarction. Am J Pathol 1990; 137: 801-10.

60. Nogami K, Kusachi S, Niiya K, Moritani H, Tsuji T. Changes in extracellular matrix components in cardiomyopathic Syrian hamster, BIO 14.6. Jpn Circ J 1995; 59: 631-40.

61. Weber KT, Janicki JS, Shroff SG, Pick R, Chen RM, Bashey RI. Collagen remodeling of the pressure-overloaded, hypertrophied nonhuman primate myocardium. Circ Res 1988; 62: 757-65.

62. Alpert NR, Hamrell RB, Halpern W. Mechanical and biochemical correlates of cardiac hypertrophy. Circ Res 1974; 34: 71-82.

63. Ratajska A, Campbell SE. Fibronectin accumulation within cardiac myocytes in rats with elevated plasm angiotensin II. Cardiovasc Pathol 1995; 4: 57-67.

64. Desmouliere A, Rubbia-Brandt L, Grau G, Gabbiani G. Heparin induces alphasmooth muscle actin expression in cultured fibroblasts and in granulation tissue myofibroblasts. Lab Invest 1992; 67: 716-26. 